\section{Challenges of Banking Profitability in Eurozone Countries:Analysis of Specific and Macroeconomic Factors}

\author{
Esat A. Durguti \\ University of Mitrovica, Economic Faculty, Kosovo \\ esat.durguti@umib.net
}

\begin{abstract}
Numerous factors affect the rate of return that a financial institution earns. Some of these factors include external forces that shape earnings performance and internal elements found in each financial institution. Policy implications are determined by the type of explanation and should be taken seriously. This paper classifies determinants of bank profitability as well as reviews existing literature on bank performance. The second section of this study quantifies how external factors and internal determinants have influenced the profitability of EU banks. This paper constructs fixed-effect models and Ordinary Least Squares (OLS), which sheds new light on understanding various factors influencing how the EU banking industry performs. The observation period was from 2012 to 2019, and the findings revealed that EU bank profitability is influenced by both external macroeconomic environment and management decisions. The results of this study suggest that equity to assets ratio (EA), Gap ratio, and GDP have a positive impact on bank profitability, while the loan to assets ratio (LA) and the provision for loan losses to total loans ratio (PLL/TL) hurt EU bank profitability. The empirical findings are consistent with the expected results, although, they are different from those of studies that investigated the structure-performance relationship of EU banks because they found that market share and concentration have a positive effect on bank profitability.
\end{abstract}

Keywords: bank profitability, regression analysis, panel data, EU countries

\section{Introduction}

Various researches have investigated bank performance to isolate factors accounting for differences in profitability among banks. These studies are divided into various categories. Some of them focused on the relationship between balance sheet structure and bank earnings performance, while others focused on the tie between aspects of bank performance and bank earnings. Other studies investigated the impact of structural, macroeconomic, or regulatory factors on overall bank performance. People usually use the term bank structure, especially when referring to features of the individual institutions. The cost of bank operation can be affected by individual bank characteristics, such as the scope of operation and portfolio composition. Additionally, the market structure can influence the price of services offered by banks as well as the quality and quantity. The economic activity of a nation also tends to determine bank profitability. In the eurozone, financial stability has been supported by recent economic expansion in the region.
ORIGINAL SCIENTIFIC PAPER

RECEIVED: MARCH 2020

REVISED: AUGUST 2020

ACCEPTED: SEPTEMBER 2020

DOI: 10.2478/ngoe-2020-0019

UDK: 336.71:330.101.541:519.233.5 (4-6EU)

JEL: G21, G23, G33

Citation: Durguti, E. A. (2020). Challenges of Banking Profitability in Eurozone Countries: Analysis of Specific and Macroeconomic Factors. Naše gospodarstvo/Our Economy, 66(4), 1-10. DOI: 10.2478/ngoe-2020-0019
NG OE

NAŠE GOSPODARSTVO OUR ECONOMY

\begin{tabular}{l|l|l} 
Vol. 66 & No. 4 & 2020 \\
\hline
\end{tabular}

p. $1-10$ 
But risks have been heightened by the softening of growth prospects. These risks have led to imbalances in both the financial and non-financial sectors and a decrease in bank profitability. Indeed, the deterioration of the macro outlook has rendered some of the challenges more acute. Due to these risks and challenges, it is now necessary to investigate factors that influence bank profitability in European Countries. To identify factors influencing bank profitability, this paper split them into two large groups, namely: external (macroeconomic) factors and internal (bank-specific) factors. The reason for examining these factors is that bank profitability is crucial for the overall financial stability of a nation. Therefore, improving bank profitability will improve the overall performance of an economy.

Numerous, investigation has been done analyzing a particular economic area (i.e. country), analogous the investigation of Mamatzakis and Panagiotis (2003), which measured the factor-profitability relationship in Greece, as well as Saeed (2014) and Kosmidou, Pasiouras, Doumpos, and Zopounidis, (2006), that evaluated the topic based on data from Great Britain. The single-market examination was productive and produced a significant number of researched countries. Williams (2003) focused on Australia, Naceur and Goaied (2001), as well as Ines, Ben, and Mhiri (2013) studied Tunisia, Sufian, and Chong (2008) focused on the Philippines, and later, Sufian and Habibullah (2009) researched China. The effectiveness factors in the United States (USA) were evaluated by Wheelock and Wilson (1995), as well as Miller and Noulas, (1997), while profitability factors in Switzerland have been analyzed by Dietrich and Wanzenried (2011).

Also, a considerable number of studies have been conducted involving states that showed in their findings that interest rates, inflation, and concentration index have a positive impact on return on equity (Goddard, Molyneux, Wilson and Takavoli, 2007); (Mendes \& Abreu, 2007); (Staikouras \& Wood, 2003). Otherwise, up-to-date revisions on the European Union banking structure were presented by Menicucci and Paolucci (2016) and Petria, Capraru, and Ihnatov (2015); for the countries of Central and Eastern Europe, Căpraru and Ihnatov (2014) and Durguti et al. (2020) have analyzed the determinants that influence the profitability of the banking system in Kosovo, covering the period 20062019. According to this study, the capital-to-asset, management efficiency, non-performing loans, inflation rate, and real exchange rate all had an impact on bank profitability. Furthermore, Tmava et al. (2019) examined the degree of profitability in the banking system of the Western Balkan countries, examining how specific factors such as assets, loans, loans-to-deposits, non-performing loans, and interest rates have affected the profitability of the Western Balkans banking system, in the individual countries.

\section{Theoretical Background}

A bank's determinants of profitability can either be internal or external. Those factors that are influenced by the bank's policy objectives and management decisions are classified as internal determinants. These internal factors influenced bank management actions, decisions, policies, objectives, and profitability. A study by Menicucci and Paolucci (2016) found that management decisions, especially those that view the concentration of loan portfolios, are crucial in determining the performance of banks. Various studies have also attributed good bank performance to quality management. Control of banks' performance and policies determines the management quality. Claessens et al, (2017) computed income statement and balance sheet ratios for all the federal banks in the United States. The study found a significant relationship between profitability and ratios. The researcher also suggested that emphasizing funds use, fund source management, and expense management would help in improve management. Borroni and Rossi (2019) concluded that a bank's liability and asset management, as well as non-interest cost controls and funding management, significantly affected the profitability of banks. Also, numerous studies have concluded that the primary determinant of bank profitability is expense control. Profitability improvement, thus, is due to expense management. With large differences and sizes, the efficient use of labour becomes the key determinant of profitability. Djalilov and Piesse (2016) argued that staff expenses were inversely related to the profitability of a bank because they increased the cost of operations. However, Firtescu, Terinte, Roman, and Anton (2019) found a positive relationship between a bank's total profits and staff expenses. This study suggested that high profit earned by banks was appropriated by high payroll expenditures.

External factors that determine bank profitability, however, have not been influenced by the bank's policies and decisions. Various studies have devoted a substantial effort in determining the relationship between the structure of banks and their performance. Most of these studies found a positive relationship between measures of market structure and profitability. Two competing hypotheses exist with regards to market structure and performance, the efficiency-structure (EFS) hypothesis and the traditional structure-conduct-performance hypothesis (SCP). SCP is an analytical tool that explains the connection between market structure, market conduct, and its performance, while EFS predicts that under the pressure of market competition, the efficient firm grows and defeats competition so that it earns higher profits, obtains greater market share, and becomes larger. Both EFS and SCP have been used to evaluate the determinants of banks' profitability. According to the SCP hypothesis, banks can extract mo- 
nopolistic rents in markets that are concentrated by trying to charge high loan rates or offer a low deposit. A theory that relates to this is relative-market-power, which argues that organizations having well-differentiated products and market shares can exercise power to earn supernormal profits. A study by Rossi, Borroni, Lippi, and Piva (2018) found that collusive profits occurred in Spanish, French, Dutch, and Italian banking markets. EFS challenges SCP by arguing that market concentration is not random because some organizations have superior efficiency. EFS states that efficient firms increase in market share and size because they are capable of generating high profits. To distinguish between these two hypotheses, studies used market share as an independent variable in their research. They modeled bank profitability as a function of interaction and concentration between market share and concentration.

Some studies also used a scale of regulation in banking industries as another variable. Cheng and Mevis (2019) found that loan losses and operating costs decreased sharply upon the deregulation of interstate banking. Other studies have also found that bank profitability is influenced by ownership characteristics. The basis for this is that different forms of bank ownership have varying management incentives. Another study by Del Giudice, Campanella, Dezi, and Al-Mashari (2016) found that GDP as a variable does not affect the profitability of banks. Durguti, Arifi, Tmava, and Kryeziu (2014), using the time series for the period 2006-2013 in Kosovo, investigated empirically the main factors (capital adequacy ratio, management efficiency ratio, asset quality ratio, liquidity ratio, investment to asset ratio, loan to asset ratio, and deposit to asset ratio) that have had a positive impact on the interest rate on loans. The study also used three bank profitability measures, namely: Net Interest Margin (NIM), Return on Equity (ROE), and Return on Assets (ROA). These factors had a strong influence on Kosovo's banking system's profitability. A study by Pacini, Berg, Tischer, and Johnson (2017) examined the impact of inflation on the stability of financial institutions in Europe. The study found that inflation strongly explained variations in bank profitability. For instance, the unexpected rise of inflation makes borrowers experience cash flow difficulties, which, in turn, can cause precipitate loan losses due to premature termination of loan arrangements. Additionally, inflation accounted for margins and operations of banks through interest rates. Barra and Zotti (2018) also claimed that variable and high inflation affected bank earnings because it makes it difficult for the bank to assess loan decisions. Also, problems in planning and negotiation for loans may arise due to inflation. Finally, inflation leads to bank financing investment that may lead to the profitability of losses, depending on the monetary policy implemented by banks.
Lastly, Detragiache, Tressel, and Turk-Ariss (2018) established that bank profitability was influenced by numerous factors, usually termed "demand" factors. To quantify all these factors is difficult, but the level of changes in income and population is very important. The level of bank earnings was, furthermore, strongly influenced by a state's per capita income within that country. On the other hand, Barra and Zotti (2018) argued that bank profits do not depend on per capita income because it may not be a good proxy for shocks in the economy that influence earnings in the banking industry. Another study by Martinho, Oliveria, \& Oliveria (2017), determined that conditions such as regional employment significantly contributed to both returns on assets and bank asset quality. On the other side, Pacini et al. (2017) suggested that bank profitability depends on the location. Based on the assessment of this literature in the field of financial productivity, this revision intends to verify the following hypotheses beginning with a brief explanation of the variables under study.

\section{Loan to assets}

Loans-to-Assets (LA) ratio: This ratio measures a bank's total loans outstanding as a percentage of its total assets. If the ratio is high, an organization's liquidity is low because it shows that it is loaned up (Meriç, Kamışlı, \& Temizel, 2017). Therefore, the higher the ratio, the riskier a bank. Several studies have concluded that the valuation of lending potential can be assessed through the loans-to-assets ratio and, thus, it is negatively correlated with the profitability of banks.

H1: There is a negative correlation between the loans to assets ratio (LA) and bank profitability.

\section{Equity to assets}

Equity-to-Asset (EA) ratio: This ratio measures the amount of equity a firm or business has compared to its total assets (Christaria \& Kurnia, 2016). It shows the percentage of a company that is funded by equity shares. To determine this ratio, the net worth of an organization is divided by its total assets.

H2: There is a positive correlation between the equity-to-assets ratio (EA) and bank profitability.

\section{Provision for loan losses to total loans}

Provision for loan losses-to-total loans (PLL/TL) ratio: this is a percentage of expenses set aside as an allowance for uncollected loan payments (Linares-Mustarós, Coenders, \& Vives-Mestres, 2018). This provision is usually used to cover various factors associated with loan losses, 
such as renegotiated terms of a loan, customer defaults, and bad loans.

H3: There is a negative correlation between provision for loan losses to total loans (PLL/TL) and bank profitability.

\section{Natural logarithm of the total assets}

Natural logarithm of the total assets ratio measures a company's short-term investments against its expenditure in the short-term. Natural logarithm of the total assets for each financial institution $\{\ln$ (assets)\}: this ratio analyses insider rates versus outsider rates in bank lending (Meriç, Kamışlı, \& Temizel, 2017). This ratio also measures the capital strength of a bank in a given year.

H4: There is a positive correlation between the natural logarithm of total assets (In [assets]) and bank profitability.

\section{Market share}

Market share (MSH): this is the percentage of all products in a category that a firm sells. Its calculation is obtained by dividing a business' sales by the total assets in a category. Companies that have low market shares are not viable (Linares-Mustarós, Coenders, \& Vives-Mestres, 2018).

H5: There is a positive correlation between market share (MSH) and bank profitability.

\section{Total assets}

Total Assets (OA): this refers to the total amount of assets a company owns. They are calculated in terms of economic value and are expended over time so that they can benefit the owner (Christaria \& Kurnia, 2016). These assets usually appear in the business' balance sheet. Return on Assets: this ratio shows the percentage of how profitable a company's assets are in generating revenue. That ratio measures a firm's management in generating revenues from their assets or economic resources (Christaria \& Kurnia, 2016).

H6: There is a negative correlation between total assets (TA) and bank profitability.

\section{Herfindahl index}

Herfindahl index $(H)$ : this is a measure of the size of a company in relation to what indicates the level of competition among them. A low concentration indicates that the industry operates within a closer to perfect competition scenario (Linares-Mustarós, Coenders, \& Vives-Mestres, 2018).

H7: There is a negative/positive impact between the Herfindahl index $(H)$ and bank profitability.

\section{Gap ratio}

Gap ratio: this is a ratio of sensitive assets of a company to its sensitive liabilities. 'Rate sensitive' indicates that liabilities and assets fall or rise significantly due to changes in interest rates (Linares-Mustarós, Coenders \& Vives-Mestres, 2018).

H8: There is a positive correlation between the Gap ratio ( $G$ ratio) and bank profitability.

\section{Gross domestic product growth}

GDP growth: this is a measure of how fast an economy is growing. Economists achieve it by comparing one-quarter of a country's GDP to the previous quarter (Christaria \& Kurnia, 2016). Therefore, the GDP measures a nation's economic output. GPI: this is a measure of economic activity that includes negative economic factors, such as the cost of underemployment and income inequality (Linares-Mustarós, Coenders, \& Vives-Mestres, 2018). GPI, thus, makes it possible to measure the quality of life in more than just cents and dollars.

H9: There is a positive correlation between GDP growth (DGDP) and bank profitability.

\section{Inflation rate}

Inflation rate: this is a measure of the rate at which average prices of goods and services in an economy rise over a certain period (Meriç, Kamışlı, \& Temizel, 2017). It is usually expressed as a percentage; hence, it indicates a decrease in the purchasing power of a currency of a nation.

H10: There is a positive correlation between inflation rate (INT) and bank profitability.

\section{Methodology and Data}

This study obtained income statements and balance sheets from the International Bank Credit Analysis (IBCA) Ltd. The data used were for the period 2012 to 2019. All the statements were consolidated as of Dec. 31 of every year, and the calculations were in euros (EUR). The study worked with a balanced sample that covered all the EU banking industries. The main reason for doing so was to ensure that the results of the study were accurate and reliable. The data were pooled to account for cross-sectional differences and simultaneous considerations. This study consisted of large numbers of cross-sectional units, but it made a few time-series observations for each bank. The study also approached panel techniques that sought to exploit the time-series dimension of data to ensure that more 
powerful tests were achieved. Apart from time-series analysis, cross-sectional regressions were also done. Therefore, this econometric analysis utilized regressions and time-series analysis for the econometric analysis.

The data in the sample also included accounts of subsidiaries of foreign banks. Various reasons made it difficult to omit foreign bank subsidiaries. One of them was that there was no sub-market data when defining the extent of the market. As the study aimed to evaluate bank profitability across various European markets, the market definition included assets of both foreign and domestic banks. From the literature review, it was evident that bank profitability was influenced by a variety of determinations. However, it was challenging to determine whether all of these factors were significant in determining bank profitability. As mentioned earlier, the literature review suggested that both internal and external factors determined bank profitability. This study employed four variables to account for firm-specific risk because the performance measure was not risk-adjusted. One of them was the loans-to-assets ratio (LA), which provided risk because loans are riskier compared to bank assets. Another one was the equity-to-assets ratio (EA), which measured the overall capital strength. This variable captured the average general safety of a financial institution.

Deterioration in this ratio revealed that debt financing was increasing or a decline in the bank's total asset, which is financially unhealthy. This study also used the provision for loan losses-to-total loans (PLL/TL), which measures capital risk. This study determined that the dataset did not provide figures for Germany's ratio. Finally, this study used the gap-to-assets ratio to differentiate the liabilities and assets of various financial institutions. The literature from previous studies revealed that the distribution of different sizes of firms in various countries and industries can be approximated using skewed distributions. The natural logarithm captures the size effect for each bank. To reduce the scale effect, this study used the log of assets. This helped in controlling the risk variable related to different seizes of financial institutions and ensured the diversification of larger banks. This made it necessary to apply a long time series t estimate a cost function for banks. To analyze data, this study followed a simpler approach to measure efficiencies in the banking industry. The expectation for this was an inverse relationship with profitability.

Finally, this study included the GDP's growth rate as well as GPI (gross personal income) for each European country. Both the GPI and GDP affected the demand and supply for deposits and loans in EU banks. Real GDP drives bank profitability in various ways. First, the position of the circle influences bank asset quality. Also, default risk is related to loan loss provisions. Bank profitability will be positively related to GDP because, during upturns, there will be high demand for bank credits. Also, GDP can be used to measure market size because the larger the market size, the higher the GDP. In contrast, a negative coefficient may exist because countries with higher GPI or GDP have

Table 1. Small and large banks in the sample

\begin{tabular}{|c|c|c|c|}
\hline Professors Country & Small banks & Large banks & Total \\
\hline Greece & 4 & 4 & 8 \\
\hline Netherlands & 14 & 5 & 19 \\
\hline Portugal & 13 & 7 & 20 \\
\hline Belgium & 18 & 7 & 25 \\
\hline Italy & 163 & 25 & 188 \\
\hline UK & 51 & 15 & 66 \\
\hline Finland & 2 & 4 & 6 \\
\hline Denmark & 56 & 5 & 61 \\
\hline France & 176 & 34 & 188 \\
\hline Spain & 42 & 19 & 61 \\
\hline Germany & 0 & 1 & 1 \\
\hline Ireland & 5 & 3 & 8 \\
\hline Sweden & 3 & 9 & 12 \\
\hline Total & 547 & 138 & 685 \\
\hline
\end{tabular}


financial institutions that operate in a mature environment, thus, leading to competitive profit margins and interest rates. This study also utilized data from the national statistics published in International Financial Statistics. The sample for the study included six hundred and eighty-five banks in Europe (547 small banks and 138 large banks). Table 1 shows shows the number of banks in the sample.

The summary for statistics is provided in table 2 below. The standard deviation of profits rates is 1.2726 , while the mean is 0.9297 . The LA ratio had a mean value of $54 \%$ and a standard deviation of $20 \%$. The significant variation of equity was $3.92 \%$, with an average of 0.077 of total assets.
The mean values for dGPI and dGDP have similar levels. It is also worth mentioning that there is a high variability of the market share and PLL/TL variable (11.08\% and 2.64\%, respectively). Lastly, the total assets (OA) had a significant positive kurtosis, while ROA had negative skewness.

The correlation matrix is presented in table 3 . The variables were selected in the order of their highest correlation with dependent variables. The study found a significant positive relationship between EA and ROA variables. It also found a negative correlation between OA and EA variables.

Table 2. Descriptive Statistics

\begin{tabular}{lccccccc} 
& mean & -variance & Std. Dev. & Skew. & Kurt. & Min. & Max. \\
\hline LA & 54.0069 & 370.6758 & 19.2529 & 0.0861 & -0.1490 & 0.3310 & 99.5503 \\
\hline Ln. assets & 14.5790 & 3.6019 & 1.8978 & 0.3907 & 0.0901 & 9.3393 & 20.3752 \\
\hline ROA & 0.9297 & 1.6245 & 1.2746 & -4.7911 & 75.2807 & -22.6530 & 14.6611 \\
\hline OA & 2.9963 & 1.9696 & 1.4034 & 0.8463 & 4.1734 & 0.0398 & 15.2950 \\
\hline Gap & 0.0603 & 0.0024 & 0.0485 & 0.1074 & 1.3588 & -0.1831 & 0.3796 \\
\hline H & 786.6545 & 263129.20 & 512.9612 & 1.9231 & 3.3595 & 249.2857 & 3637.543 \\
\hline EA & 7.7217 & 15.3816 & 3.9219 & 0.9458 & 1.6346 & -11.2884 & 38.4245 \\
\hline MSH & 2.4319 & 122.7822 & 11.0807 & 9.4619 & 110.2415 & 0.0015 & 179.0446 \\
\hline PLL/TL & 1.1386 & 6.9922 & 2.6440 & 9.7118 & 271.7168 & -37.0154 & 77.7832 \\
\hline DGDP & 4.8098 & 268.3048 & 16.3800 & 3.9170 & 24.3683 & -37.2823 & 106.4748 \\
\hline INT & 6.1488 & 5.8432 & 2.4173 & 2.0506 & 12.9465 & 3.0754 & 227.2734 \\
\hline
\end{tabular}

Table 3. Correlation between variables

\begin{tabular}{|c|c|c|c|c|c|c|c|c|c|c|}
\hline & Lnas & ROA & $\mathrm{OA}$ & Gap & $\mathrm{H}$ & EA & $\mathrm{MSH}$ & LLP/TL & DGDP & INT \\
\hline Lnas & 1.000 & & & & & & & & & \\
\hline ROA & 0.360 & 1.000 & & & & & & & & \\
\hline $\mathrm{OA}$ & 0.110 & -0.410 & 1.000 & & & & & & & \\
\hline Gap & 0.320 & -0.231 & 0.063 & 1.000 & & & & & & \\
\hline $\mathrm{H}$ & 0.080 & -0.022 & 0.021 & 0.320 & 1.000 & & & & & \\
\hline EA & 0.390 & -0.511 & -0.070 & -0.010 & 0.376 & 1.000 & & & & \\
\hline MSH & 0.010 & 0.430 & -0.183 & 0.694 & -0.167 & -0.012 & 1.000 & & & \\
\hline LLP/TL & -0.430 & -0.090 & 0.064 & -0.032 & 0.371 & -0.163 & -0144 & 1.000 & & \\
\hline DGDP & -0.080 & -0.080 & 0.001 & -0.011 & 0.043 & 0.076 & 0033 & 0.033 & 1.000 & \\
\hline INT & 0.080 & -0.020 & 0.021 & 0.010 & 0.204 & -0.022 & 0.087 & 0.221 & 0287 & 1.000 \\
\hline
\end{tabular}




\section{Results and Discussion}

This study adopted a multiple regression framework to help in testing the hypothesis regarding factors of EU bank profitability. This paper used the fixed-effect model because there is a correlation between independent variables and the individual-specific effects. The basic equation for this study is:

$\mathrm{DEP}_{\mathrm{jit}}=\alpha+\beta_{1} \mathrm{LA}_{\mathrm{jit}}+\beta_{2} \mathrm{EA}_{\mathrm{jit}}+\beta_{3} \frac{\mathrm{LLL}}{\mathrm{TL}}{ }_{\mathrm{jit}}+\beta_{4} \mathrm{LnAssets}_{\mathrm{jit}}+\beta_{5} \mathrm{MSH}_{\mathrm{jit}}$

$+\beta_{6} \mathrm{OA}_{\mathrm{jit}}+\beta_{7} \mathrm{H}_{\mathrm{jit}}+\beta_{8} \mathrm{Gap}_{\mathrm{jit}}+\beta_{9} \mathrm{DGDP}_{\mathrm{jit}}+\beta_{10} \mathrm{INT}_{\mathrm{jit}}+\mu_{\mathrm{jit}}$

where $\mathrm{j}$ refers to the country of operation, $\mathrm{i}$ is the individual bank, while t refers to the time.

For each group of regression results and at each stage of model building, this study performed the regression with all variables as well as examined results. The observations in this study were 2,425, with a satisfactory level of 0.68 . The regression's standard error is 0.0731 , while the significant positive and negative effects were 4.5202 and -8.4756, respectively. The DW test was 1.78 ; hence, either negative or positive first-order correlation exists. R-squared was at a satisfactory level of 0.71 , while the adjusted R-square was at 0.63 . The results showed that, at the $5 \%$ level in the regression model, all variables were significant. These variables had the expected sign. The results of the Hausman test revealed that it is more appropriate to use fixed effects rather than random effects. The level of interest rates and the change of GDP had a significant positive effect (t-statistics = 4.5202), while the market structure variables had significant negative effects $(\mathrm{t}$-statistics $=-8.4756)$. Apart from the variables mentioned above, all others had expected signs with significant influence. Table 4 shows the results. It is clear that loan to assets, equity to assets, provision for loan losses to total loans, the natural logarithm of assets, total assets, gap, GDP growth, and inflation consume important positive or adverse effects on banks productivity. While market share and the Herfindahl index are non-significant influences on profitability. The hypotheses of this study will be presented below as well as their sound effects on the expected results. Hypothesis 1: loans to assets in relation to productivity retained a negative impact, by a significance level of $1 \%$, and the hypothesis was confirmed. The result is fully in mark with the findings of Hasan MK and Bashir (2003) and Staikouras and Wood (2004), who found that if the banks increased loan volume along with lower margins, it could be presumed to hurt profitability. Hypothesis 2: equity to assets or known capital adequacy ratio in relation to profitability has a positive influence on the productivity of banks, through an importance level of $1 \%$, and the hypothesis is confirmed. The results are in line with the findings of Durguti, et al, (2020) and Menicucci and Paolucci, (2016) who found that banks with more capital have greater protection from insolvency.

Hypothesis 3: provision for loan losses to the total loan is confirmed with a significance level of $1 \%$ and with a negative impact on the bank's profitability. Based on this, any

Table 4. Empirical Results

\begin{tabular}{|c|c|c|c|c|}
\hline & s 0.0731 & \multicolumn{3}{|c|}{ Durbin Watson is 1.7816} \\
\hline \multicolumn{2}{|c|}{ Residual's variance is 0.5977} & \multicolumn{3}{|c|}{ LM het. Test is 444.3840} \\
\hline \multicolumn{2}{|c|}{ The sum of the squared residuals is 1630.4} & \multicolumn{3}{|c|}{ R-squared is 0.7069} \\
\hline & & \multicolumn{3}{|c|}{ Adjusted R-squared is 0.6321} \\
\hline Variable & Std. Error & Est. Coefficient & p-value & t-stats \\
\hline LA & 0.0031 & -0.0119 & {$[0.000]$} & -3.8547 \\
\hline EA & 0.0147 & 0.1968 & [0.000] & 13.3499 \\
\hline LLP/TL & 0.0068 & -0.1806 & [0.000] & -26.4952 \\
\hline Lnas & 0.0820 & 0.7022 & {$[0.000]$} & 8.5659 \\
\hline MSH & 0.0109 & -0.0104 & [0.343] & -0.9488 \\
\hline $\mathrm{OA}$ & 0.0335 & -0.1860 & [0.000] & -5.5549 \\
\hline $\mathrm{H}$ & 0.0002 & 0.0000 & [0.812] & -0.2379 \\
\hline Gap & 0.8495 & 2.1827 & [0.010] & 2.5695 \\
\hline DGDP & 0.0009 & 0.0076 & [0.000] & 8.4756 \\
\hline INT & 0.0188 & 0.0537 & [0.000] & 4.5202 \\
\hline
\end{tabular}


growth in this percentage has an impact on reducing the profit of banks. In this sense, the authors, Miller and Noulas (1997), have found that there is a negative relationship between credit risk (inadequate credit risk), which obliges banks to raise the provision for loan losses with the profitability of banks. The natural logarithm assets indicator revolved out to be significant with a positive impact on the profitability of banks and, at a similar time, the confirmation of hypothesis 4 is completed in the framework of this study. This study is in full accordance with the study conducted by the authors Durguti et al. (2020) and their findings were that assets had a positive impact on increasing profitability. Total assets defined in hypothesis 6 turned out to be significant at the level of $1 \%$, with a negative impact on the profitability of banks, and this result was similar to the study directed by the authors Christaria and Kurnia (2016). They found that banks that had sound assets had the financial capacity to support their customers, but their inadequate management turned out to have a negative impact on the profitability of banks. Hypothesis 8 is also confirmed at the level of importance $10 \%$, with a positive impact on the profitability of banks. Hypothesis 9 was proven on GDP growth in banks' profitability is confirmed at the importance level of $1 \%$ with a positive effect. The T-statistic of this variable was 8.4756. The results of our study have been in line with those of Athanasoglou et al. (2008) and Albertazzi and Gambacorta (2009). They assumed that bank profitability depended primarily on growth, except for those countries where international groups can own assets. And finally, in hypothesis 10 , the inflation rate was confirmed with a significance level of $1 \%$ and had a positive impact on increasing the productivity of banks. The effects were paralleled with the authors Tan and Floros (2012), who discovered the profitability of banks in China over the period 2003-2009. They used the GMM technique and established that employment productivity, stock market expansion, cost-effectiveness, and inflation have a highly positive effect on banks' profit. Hypotheses 5 and 7 were not confirmed or rejected as their value was non-significant and, as such, was irrelevant to treatment.

\section{Size Effects}

This study split the banks based on the cut-off point defined earlier for the financial institutions' size. In this case, the sample consisted of two sub-samples: 547 small banks and 138 large banks. Table 4 above introduced all the variables in the model. All of them were significant with the expected sign, except three variables, namely: $\mathrm{H}, \mathrm{MH}$, and DGPI.
For small banks, the t-statistics were more significant than those of the large banks. The results of this study support the recent researches that argued that bank profitability depends on both internal and external factors.

\section{Conclusion}

It is essential to test the robustness of banks' profitability because it sheds light on the assessment of banks' performance. This study is significant to the current ongoing restructuring and consolidation of the banking markets in Europe. Banks need to note that both internal and external factors are crucial in determining their performances. Other crucial factors for bank profitability are market structure and pricing by financial institutions. It is, thus, important for banks to take these factors seriously. EU bank profitability is influenced not only by internal factors but also by changes in the external environment. Financial institutions with greater levels of equity generate higher profits. Also, banks that have large non-loan assets are more profitable. The results of this study are in contrast with those that investigated structure-performance relationships for EU banks because those studies found that profitability relates positively to market share variables. Confirmation/rejection of these hypotheses was done at a significance level of $1 \%$, $5 \%$, and $10 \%$. The results overhead illustrations that out of the 10 factors applied in the analysis, 8 of them were confirmed to affect the profitability of banks (in EU countries), and only two of them had no impact.

The empirical results of this study reveal that various variables are crucial in determining the profitability of EU banks. The EA ratio consistently had the same level of significance and sign, which reveals that banks with higher levels of equity are more profitable than others. There was also an inverse relationship between the LA ratio and the bank returns on assets. The implication of this is that a bank is more profitable if it has a great many non-loan earning assets than when it relies heavily on assets. The PLL/TL ratio was significantly negative, and the funds' Gap ratio was significantly positive. In either regression, no significant differences existed in the MSH variable. The variable was found to be negative and unstable in some regressions. However, the exclusion of the loan reserve variable negated the concentration. The variability of the GDP growth rates and interest were negative, while the level of interest rates was positive. 


\section{References}

Albertazzi, U., \& Gambacorta, L. (2009). Bank profitability and the business cycle. Journal of Financial Stability, 5(4),393-409. http://dx.doi.org/10.1016/j.jfs.2008.10.002.

Athanasoglou, P.P., Brissimis, S.N., \& Delis, M. (2008). Bank specific, industry-specific and macroeconomic determinants of bank profitability. Journal of International Financial Markets, Institutions and Money, 18(2),121-136. http://dx.doi.org/10.1016/j.intfin.2006.07.001

Barra, C. \& Zotti, R. (2018). Financial stability as a public policy goal to increase local economic development: An empirical investigation from Italian labour market areas (No. 154). CELPE-Centre of Labour Economics and Economic Policy, University of Salerno, Italy.

Borroni, M. \& Rossi, S. (2019). Bank profitability: Measures and determinants. Banking in Europe Banking in Europe. Palgrave Macmillan Studies in Banking and Financial Institutions. Palgrave Pivot, Cham. 23-53. https://doi.org/10.1007/978-3-030-15013-6_2.

Cheng, G. \& Mevis, D. (2019). What happened to profitability? Shocks, challenges, and perspectives for euro area banks. The European Journal of Finance, 25(1), 54-78. https://doi.org/10.1080/1351847X.2018.1470994

Christaria, F. \& Kurnia, R. (2016). The Impact of financial ratios, operational efficiency and non-performing loan towards commercial bank profitability. Accounting and Finance Review AFR, 1, 43-50. https://ssrn.com/abstract=3000205

Claessens, S., Coleman, N., \& Donnelly, M. (2018). Low-For-Long interest rates and banks' interest margins and profitability: Cross-country evidence, Journal of Financial Intermediation, 35(A), 1-16, ISSN 1042-9573, https://doi.org/10.1016/j.jfi.2017.05.004.

Del Giudice, M., Campanella, F., Dezi, L., \& Al-Mashari, M. (2016). The bank of things: An empirical investigation on the profitability of the financial services of the future. Business Process Management Journal. https://doi.org/10.1108/BPMJ-10-2015-0139.

Detragiache, M.E., Tressel, M.T., \& Turk-Ariss, R. (2018). Where have all the profits gone? European bank profitability over the financial cycle. International Monetary Fund. ISBN/ISSN 9781484354544/1018-5941.

Dietrich A, \& Wanzenried G. (2011). Determinants of bank profitability before and during the crisis: Evidence from Switzerland. Journal of International Financial Markets, Institutions and Money 21(3) 307-327. http://dx.doi.org/10.2139/ssrn.1370245

Durguti, E. A., Krasniqi, E. H., \& Krasniqi, D. (2020). Assessing the performance of factors affecting the profitability of the banking system: Evidence from Kosovo. European Journal of Sustainable Development, 9(2), 304. https://doi.org/10.14207/ejsd.2020. v9n2p304

Durguti, E., Zhuja, D., \& Arifi, E. (2014). An examination of the net interest margin as determinants of banks' profitability in the Kosovo banking system. European Academic Research, 2(5), 6350-6364. https://doi.org/10.13140/RG.2.2.24588.46720

Firtescu, B.N., Terinte, P.A., Roman, A., \& Anton, S.G. (2019). Corporate governance and bank profitability: An empirical assessment for emerging Europe. Transformations in Business \& Economics, 18. https://doi.org/10.2478/saeb-2018-0020

Goddard, J., Molyneux, P., Wilson, J. O. S., \& Tavakoli, M. (2007). European banking: An overview. Journal of Banking and Finance, 31(7), 1911-1935. https://doi.org/10.1016/j.jbankfin.2007.01.002

Hassan M.K. \& Bashir A. M. (2003). Determinants of Islamic Banking Profitability, Paper Presented at the Economic Research Forum (ERF) 10th Annual Conference, Marrakech. Marocco, 16-18 December 2003. DOI:10.3366/edinburgh/9780748621002.003.0008

Ines, B., Ben, G., \& Mhiri, S. M. (2013). Explanatory factors of bank performance in Tunisia: A panel model approach. Global Journal of Management and Business Research Finance, 13(5).

Kosmidou, K., Pasiouras, F., Doumpos, M., \& Zopounidis, C. (2006). Assessing performance factors in the UK banking sector: A multicriteria methodology. Central European Journal of Operations Research, 14(1), 25-44. https://doi.org/10.1007/s10100-0060158-5.

Linares-Mustarós, S., Coenders, G. \& Vives-Mestres, M. (2018). Financial performance and distress profiles. From classification according to financial ratios to compositional classification. Advances in Accounting, 40, 1-10. https://doi.org/10.1016/j.adiac.2017.10.003.

Mamatzakis, E., \& Panagiotis, R. (2003). Determinants of Greek commercial banks, 1989-2000. SPOUDAl- Journal of Economics and Business, 53(1), 84-94. http://sro.sussex.ac.uk/id/eprint/40071.

Martinho, R., Oliveria, J. \& Oliveria, V. (2017). Bank Profitability and Macroeconomic Factors. Financial stability papers, Banco de Portugal, Lisbon, 2183-4059.

Mendes, V., \& Abreu, M. (2003). Do macro-financial variables matter for European bank interest margins and profitability? EcoMod2003 - International Conference on Policy Modeling, 1-12.

Menicucci, E. \& Paolucci, G. (2016). Factors affecting bank profitability in Europe: An empirical investigation. African Journal of Business Management, 10(17), 410. https://doi.org/10.5897/AJBM2016.808.

Meriç, E., Kamışlı, M. \& Temizel, F. (2017). Interactions among stock price and financial ratios: The case of the Turkish banking sector. Applied Economics and Finance, 4(6), 107-115. https://doi.org/10.11114/aef.v4i6.2755.

Miller, S. M., \& Noulas, A. G. (1997). Portfolio mix and large-bank profitability in the USA. Applied Economics, 29(4), 505-512. https:// doi.org/10.1080/000368497326994.

Naceur, S. Ben, \& Goaied, M. (2001). The determinants of the Tunisian deposit banks' performance. Applied Financial Economics, 11(3), 317-319. https://doi.org/10.1080/096031001300138717. 
Pacini, K., Berg, D., Tischer, T. \& Johnson, J. (2017). An empirical investigation of macroeconomic factors on firm performance in the United Kingdom. Available at SSRN 3013944.

Petria, N., Capraru, B., \& Ihnatov, I. (2015). Determinants of banks' profitability: Evidence from EU 27 banking systems. Procedia Economics and Finance, 20, 518-524. https://doi.org/10.1016/S2212-5671(15)00104-5.

Rossi, S., Borroni, M., Lippi, A., \& Piva, M. (2018). Determinants of Bank Profitability in the Euro Area: What has changed during the recent financial crisis? International Business Research, 11(5). https://doi.org/:10.5539/ibr.v11n5p18

Saeed, M. S. (2014). Bank-related, industry-related and macroeconomic factors affecting bank profitability: A case of the United Kingdom. Research Journal of Finance and Accounting, 5(2), 2222-2847.

Staikouras, C.K., \& Wood, G.E. (2004). The determinants of European bank profitability. Int. Bus. Econ. Res. J. 3(6), 57-68.

Miller, S. \& Noulas, A. (1997) Portfolio mix and large-bank profitability in the USA, Applied Economics, 29(4), 505512, DOI: $10.1080 / 000368497326994$

Sufian,F., \& Chong, R.R.(2008). Determinants of bank profitability in a developing economy: empirical evidence from the Philippines. Asian Academy of Management Journal of Accounting and Finance, 4(2), 91-112. https://doi.org/10.1080/10599230903340205

Sufian, F., \& Habibullah, M. S. (2009). Bank specific and macroeconomic determinants of bank profitability: Empirical evidence from the China banking sector. Frontiers of Economics in China, 4(2), 274-291. https://doi.org/10.1007/s11459-009-0016-1.

Tan Y, \& Floros C. (2012). Bank profitability and inflation: the case of China. Journal of Economic Studies 39(3), 675-696. https:// doi.org/10.1108/01443581211274610

Tmava, Q., Berisha, F., \& Mehmeti, M. (2019). Comparative analysis of banking system profitability in Western Balkan countries. Journal of Economics and Management Science, 2(2), 139-152. https://doi.org/10.30560/jems.v2n2p33.

Wheelock, D. C., \& Wilson, P. W. (1995). Evaluating the efficiency of commercial banks: Does our view of what Banks do matter? Federal Reserve Bank of St. Louis Review, 77(4), 39-52.

Williams, B. (2003). Domestic and international determinants of bank profits: Foreign banks in Australia. Journal of Banking and Finance, 27(6), 1185-1210. https://doi.org/10.1016/S0378-4266(02)00251-0.

\section{Izzivi donosnosti bank v državah evrskega območja: analiza posebnih in makroekonomskih dejavnikov}

\section{Izvleček}

Na donosnost finančne institucije vplivajo številni dejavniki. Nekateri od teh dejavnikov vključujejo zunanje sile, ki oblikujejo rezultate na področju dobička, in notranje elemente, ki so prisotni v vsaki finančni instituciji. Politični vplivi so odvisni od vrste razlage in jih je treba jemati resno. Ta članek razvršča determinante donosnosti bank, hkrati pa služi kot pregled obstoječe literature o uspešnosti bank. Drugi del te raziskave meri, kako zunanji dejavniki in notranje determinante vplivajo na donosnost bank v EU. Članek vsebuje modele s fiksnim učinkom in OLS (metode najmanjših kvadratov) ter v novi luči prikazuje različne dejavnike, ki vplivajo na uspešnost bančnega sektorja EU. Obdobje opazovanja je bilo od leta 2012 do 2019 in ugotovitve kažejo, da na donosnost bank v EU vplivata tako zunanje makroekonomsko okolje kot upravljavsko odločanje. Rezultati študije kažejo, da razmerje med kapitalom in premoženjem (EA), razmerje vrzeli in BDP pozitivno vplivajo na donosnost bank, medtem ko razmerje med posojili in premoženjem (LA) ter razmerje med rezervacijami za posojilne izgube in skupnimi posojili (PLL/TL) negativno vplivata na donosnost bank v EU. Empirične ugotovitve se ujemajo s pričakovanimi rezultati, vendar se razlikujejo od študij, ki so proučevale razmerje med strukturno uspešnostjo bank v EU, ker ugotavljajo, da tržni delež in koncentracija pozitivno vplivata na donosnost bank.

Ključne besede: donosnost bank, regresijska analiza, panelni podatki, države EU 